\title{
Effect of Good Agricultural Practices on Energy Use in Citrus Farming in Turkey: Case of Mersin Province
}

\section{Osman UYSAL ${ }^{1}$ (i) Başak AYDIN ${ }^{2}$ (D) Osman Sedat SUBAŞI Erkan AKTAŞ ${ }^{4}$}

\author{
${ }^{1}$ Malatya Turgut Özal University Faculty of Agriculture Department of Agricultural Economics, 44210, \\ Malatya, Turkey \\ ${ }^{2}$ Atatürk Soil and Water Agricultural Meteorology Research Institute, 39060, Kırklareli, Turkey \\ ${ }^{3}$ Alata Horticultural Research Institute, 33740, Mersin, Turkey \\ ${ }^{4}$ Mersin University School of Economics and Administrative Sciences Department of Economics, 33110, \\ Mersin, Turkey
}

\section{Article History}

Received 18 June 2021

Accepted 21 October 2021

First Online 02 November 2021

\section{Corresponding Author}

E-mail: uysalosman@hotmail.com

\begin{abstract}
The study aimed to determine the energy consumption efficiency of citrus production in enterprises that applied and did not apply Good Agricultural Practices (GAP) in Turkey's Mersin province. Total of 89 citrus producers applied good agricultural practices in Mersin in 2013 and the survey was conducted with all the producers and 26 of these producers produced orange, 28 of these producers produced tangerines, and 35 of these producers produced lemon. In the study, for comparing the enterprises, the same survey was also carried out with the same number of producers who did not apply good agricultural practices. Labor, machinery, diesel, farmyard manure, fertilizers, pesticides, electricity, and water in irrigation were calculated as energy inputs, and citrus production quantities were calculated as outputs. According to research results, fertilizers were determined as the most energy-consuming inputs in citrus production. The energy use efficiency values were 1.83 and 1.53 in orange production, 1.75 and 1.48 in tangerine production, 1.66 and 1.34 in lemon production in the enterprises that applied and did not apply good agricultural practices. Therefore, the energy use efficiency that applied good agricultural practices in enterprises was determined to be higher. Energy productivity results showed that citrus producers who applied good agricultural practices could produce more output than citrus producers who did not apply good agricultural practices. Specific energy results indicated that the citrus enterprises that applied good agricultural practices consumed less energy to produce one $\mathrm{kg}$ of the product than those that did not apply good agricultural practices. Non-renewable energy shares were lower in enterprises that used good agricultural practices than in the other group. According to the study's findings, Citrus production enterprises that applied good agricultural practices were more profitable in Mersin province.
\end{abstract}

\section{Introduction}

Citrus is a plant genus that includes several high-value fruits such as orange, tangerine, lemon, grapefruit, and sour orange. Citrus is endemic to China and India, and it can be grown virtually everywhere in a temperate environment. In Turkey, citrus farming is executed in the south, southwest, and west regions of Anatolia (Anonymous, 2020). Citrus, includes the $\mathrm{C}$ vitamin, has significant benefits for human health, and it is evaluated as jam, marmalade, and fruit juice besides the edible consumption and used as a raw material in the cosmetic sector (Uysal and Polatöz, 2017).

According to USDA data, by $2019 / 2020$ production season, a total of 92 million tons citrus production, 46 million ton of which was orange, 32 million ton of which was tangerine, 8 million ton of which was lemon, and 7 million ton of which was sour orange, were done in the World. In other 
words, $50 \%, 34 \%, 8 \%$, and $7 \%$ of this production belonged to orange, tangerine, lemon, and sour orange, respectively. Thus, Turkey takes seventh place in orange production, third place in tangerine production, fourth place in lemon production, and fifth place in sour orange production (USDA, 2020).

In Turkey, 1 million 334 thousand tons of orange, 1 million 586 thousand tons of tangerine, 1 million 189 thousand tons of lemon, and 238 thousand tons of sour orange production were executed in 2020 , and $30.69 \%, 36.48 \%, 27.35 \%$, and $5.48 \%$ of citrus production belonged to orange, tangerine, lemon, and sour orange, respectively. In Mersin province, 193 thousand tons of orange, 302 thousand tons of tangerine, 702 thousand tons of lemon, and 30 thousand tons of sour orange production were performed in 2020, and $14.47 \%$, 19.07\%, 59.04\%, and $12.61 \%$ of citrus production belonged to orange, tangerine, lemon, and sour orange, respectively (Anonymous, 2021a).

Good agricultural practices (GAP) concept is a production model that keeps the agricultural production under control by not damaging the environment, human and animal health and providing sustainability and food security by the certification of the crops. Good agricultural practices are farming itself, not an alternative agricultural production model. Implementations such as chemical pesticides, fertilizers, etc., are present, but they are applied by not damaging human health and the environment in integrated crop production principles in good agricultural practices (Hasdemir, 2011).

Good agricultural practices started in 2007 in Turkey, and especially after 2013, significant developments were registered in terms of producer number and production area. The number of provinces in which good agricultural practices were executed was 18 in 2007, and this number increased to 61 in 2020. Good agricultural practices were performed with 14501 producers in 254755 ha area in Turkey in 2020. Mersin province where the production and the consumption of fruit kinds such as citrus foremost, tomato, pepper, stone fruits (apricot, peach, cherry, plum) come into prominence in good agricultural practices. Good agricultural practices were performed with 870 producers in 14704 ha areas in Mersin province in 2020 (Anonymous, 2021b).

Energy analysis is a practical approach for grouping the agricultural systems in terms of energy consumption. Although the agriculture sector is not a considerable energy consumer, significant energy consumption is present in rural areas due to soil tillage, planting, weed control, irrigation, fertilizing, harvesting, transport, and drying (Yaldız et al., 1993). Energy consumption increases by the modernization of these processes and the increase of agricultural production. Energy analysis determines how efficient energy is used, sustainable farming, a decrease in fossil fuels, environmental protection, and economic benefit provided by efficient energy usage (Bilgili, 2012).
Various studies on fruit production energy analysis were conducted, such as apricot (Gezer et al., 2003; Gundogmus, 2006), sweet cherry (Demircan et al., 2006), dry apricot (Esengün et al., 2007), cherries (Kizilaslan, 2009), pomegranate (Akcaoz et al., 2009), kiwifruit (Mohammadi et al., 2010), banana (Akcaoz, 2011), lemon (Bilgili, 2012), peach (Goktolga et al., 2006; Royan et al., 2012), pear (Liu et al., 2010; Tabatabaie et al., 2013), strawberry (Banaeian et al., 2011; Loghmanpor et al., 2013), grape (Qasemi Kordkheili and Rahbar, 2015), orange (Mohammadshirazi et al., 2015), almond (Beigi et al., 2016), organic grape (Baran et al., 2017a), organic mulberry (Gokdogan et al., 2017b), organic strawberry (Baran et al., 2017b), walnut (Gundogmus, 2013; Baran et al., 2017c), plum (Baran et al., 2017d), peach and cherry (Aydın and Aktürk, 2018), apple (Ekinci et al., 2005; Sami et al., 2011; Strapatsa et al., 2006; Dilay et al., 2010; Rafiee et al., 2010; Yilmaz et al., 2010; Fadavi et al., 2011; Akdemir et al., 2012; Celen et al., 2017; Gokdogan and Baran, 2017a; Aydın et al., 2019), nectarine (Qasemi Kordkheili et al. 2015, Oğuz et al., 2019a), organic wolfberry (Oğuz et al., 2019b), citrus (Ozkan et al., 2004; Namdari et al., 2011; Loghmanpor et al., 2013; Yılmaz and Aydın, 2020), organic almond (Baran et al., 2020),tangerine (Mohammadshirazi et al., 2012; Karabat and Aydın, 2018; Bilgili, 2021).

In this study, the inputs used in orange, tangerine, and lemon production in the enterprises were determined, and the energy equivalents of these inputs were calculated in enterprises that applied and did not apply good agricultural practices in Mersin province. In addition, comparative energy analysis was done in orange, tangerine, and lemon production in the groups, and the efficiency degrees of the inputs were determined.

\section{Materials and Methods}

The primary data for the study were collected from the citrus producers who applied and did not apply good agricultural practices in the Mersin province. Besides, the previous studies related to the subject and the statistical indicators composed the secondary of the research. Total of 89 citrus producers applied good agricultural practices in Mersin in 2013 and the survey was conducted with all the producers and 26 of these producers produced orange, 28 of these producers produced tangerines, and 35 of these producers produced lemon. The same survey was conducted in the research with the same number of producers who did not apply good agricultural practices to compare the enterprises. The energy inputs of orange, tangerine, and lemon production were labor, machinery, electricity, diesel fuel, irrigation water, farmyard manure, chemicals, and fertilizers, while orange, tangerine, and lemon fruits were production values outputs. The input and output quantities per hectare were computed and multiplied by the 
energy equivalent coefficients (Table 1). It was utilized from the previous studies in order to determine the energy equivalent coefficients. Megajoule (MJ) was used to express the energy equivalents of the inputs and outputs. The total input equivalent was computed by calculating the energy equivalents of all inputs in MJ. For determining the energy consumption in orange, tangerine, and lemon production, the following formulas were used: energy use efficiency, specific energy, energy productivity, and net energy coefficients (Mandal et al., 2002). Specific energy represents the quantity per product quantity, whereas energy productivity expresses the quantity per product quantity.

Energy Use Efficiency $=\frac{\text { Energy Output }}{\text { Energy Input }}$

Energy Productivity $=\frac{\text { Yield }}{\text { Energy Input }}$

Specific Energy $=\frac{\text { Energy Input }}{\text { Yield }}$

Net Energy = Energy Output - Energy Input
(Energy: $M J \mathrm{ha}^{-1}$, Yield: $k g h a^{-1}$ )

The energy inputs were analyzed in terms of direct, indirect, renewable, and non-renewable energy sources. Labor, diesel, irrigation water, and electricity are examples of direct energy, whereas chemical fertilizers, farmyard manure, pesticides, and machinery are examples of indirect energy. Labor, farmyard manure, and irrigation water are examples of renewable energy, whereas diesel, chemical fertilizers, pesticides, machinery, and electricity are examples of non-renewable energy.

\section{Results and Discussion}

The quantities of the inputs used in orange production and their energy equivalences are given in Table 2. Besides, Table 2 shows the quantity of the output of orange production and the energy equivalent of orange production. As is seen from

Table 1. Energy equivalents of inputs and outputs in fruit production.

\begin{tabular}{lcc}
\hline Inputs & Energy equivalent $\left(\mathrm{MJ} \mathrm{unit}^{-1}\right)$ & References \\
\hline Labor $(\mathrm{h})$ & 1.96 & Singh, 2002 \\
Machinery $(\mathrm{h})$ & 64.80 & Kizilaslan, 2009; Singh, 2002 \\
Diesel fuel $(\mathrm{l})$ & 56.31 & Singh, 2002 \\
Farmyard manure $(\mathrm{kg})$ & 0.30 & Singh, 2002 \\
Fertilizer (kg) & & \\
$\quad$ Nitrogen & 60.60 & Singh, 2002 \\
$\quad$ Phosphorus & 11.15 & Singh, 2002 \\
$\quad$ Potassium & 6.70 & Singh, 2002 \\
$\quad$ Sulfate & 1.12 & Rafiee et al., 2010 \\
Chemicals $(\mathrm{kg})$ & & \\
$\quad$ Insecticides & 101.20 & Rafiee et al., 2010 \\
$\quad$ Fungicides & 216.00 & Rafiee et al., 2010 \\
$\quad$ Herbicides & 238.00 & Rafiee et al., 2010 \\
Electricity $(\mathrm{kWh})$ & 3.60 & Ozkan et al., 2004 \\
Irrigation water $\left(\mathrm{m}^{3}\right)$ & 0.63 & Yaldiz et al., 1993 \\
\hline Output & & \\
\hline Fruit $(\mathrm{kg})$ & 2.40 & Ozkan et al., 2004 \\
\hline
\end{tabular}

Table 2. Quantities of inputs and outputs and total energy equivalents of orange production.

\begin{tabular}{|c|c|c|c|c|c|c|}
\hline \multirow[b]{2}{*}{ Inputs } & \multicolumn{3}{|c|}{ GAP orange } & \multicolumn{3}{|c|}{ Orange } \\
\hline & $\begin{array}{l}\text { Quantity per } \\
\text { unit area } \\
\text { (ha) }\end{array}$ & $\begin{array}{l}\text { Energy } \\
\text { equivalent } \\
\text { (MJ) }\end{array}$ & $\begin{array}{l}\% \text { of total } \\
\text { energy } \\
\text { input }\end{array}$ & $\begin{array}{l}\text { Quantity per } \\
\text { unit area } \\
\text { (ha) }\end{array}$ & $\begin{array}{l}\text { Energy } \\
\text { equivalent } \\
(\mathrm{MJ})\end{array}$ & $\begin{array}{l}\text { \% of total } \\
\text { energy } \\
\text { input }\end{array}$ \\
\hline Labor (h) & 699.80 & 1371.61 & 2.64 & 702.50 & 1376.90 & 2.23 \\
\hline Machinery (h) & 65.00 & 4212.00 & 8.11 & 63.00 & 4082.40 & 6.61 \\
\hline Diesel (I) & 102.50 & 5771.78 & 11.11 & 98.50 & 5546.54 & 8.99 \\
\hline $\begin{array}{l}\text { Farmyard manure } \\
(\mathrm{kg})\end{array}$ & 3200.00 & 960.00 & 1.85 & 3400.00 & 1020.00 & 1.65 \\
\hline Fertilizers (kg) & & & & & & \\
\hline Nitrogen & 336.50 & 20391.90 & 39.25 & 395.50 & 26158.37 & 42.38 \\
\hline Phosphorus & 380.00 & 4237.00 & 8.16 & 471.00 & 5859.24 & 9.49 \\
\hline Potassium & 305.00 & 2043.50 & 3.93 & 358.00 & 3991.70 & 6.47 \\
\hline Sulfate & 156.00 & 174.72 & 0.34 & 168.00 & 188.16 & 0.30 \\
\hline Pesticides (kg) & & & & & & \\
\hline Insecticides & 10.40 & 1052.48 & 2.03 & 11.20 & 1133.44 & 1.84 \\
\hline Fungicides & 12.10 & 2613.60 & 5.03 & 13.50 & 2916.20 & 4.72 \\
\hline Herbicides & 13.20 & 3141.60 & 6.05 & 13.80 & 3284.40 & 5.32 \\
\hline Electricity (kWh) & 955.00 & 3438.00 & 6.62 & 985.00 & 3546.00 & 5.74 \\
\hline Irrigation water $\left(\mathrm{m}^{3}\right)$ & 4035.00 & 2542.05 & 4.89 & 4160.00 & 2620.80 & 4.25 \\
\hline Total & & 51950.23 & 100.00 & & 61723.95 & 100.00 \\
\hline Output (Yield) & 39520.00 & 98848.00 & & 39270.00 & 94248.00 & \\
\hline
\end{tabular}


Table 2, 336.50 and $395.50 \mathrm{~kg}$ nitrogen, 380 and $471 \mathrm{~kg}$ phosphorus, 305 and $358 \mathrm{~kg}$ potassium, 156 and $168 \mathrm{~kg}$ sulfate, 3200 and $3400 \mathrm{~kg}$ of farmyard manure were used as fertilizers, 102.50 and $98.50 \mathrm{I}$ diesel fuel, 4035 and $4160 \mathrm{~m}^{3}$ irrigation water, 10.40 and $11.20 \mathrm{~kg}$ insecticides, 12.10 and $13.50 \mathrm{~kg}$ fungicides, 13.20 and $13.80 \mathrm{~kg}$ herbicides, 699.80 and $702.50 \mathrm{~h}$ labor, 65 and $63 \mathrm{~h}$ machinery, 955 and $985 \mathrm{kWh}$ electrical energy per hectare was used for the orange production that applied and did not apply good agricultural practices, respectively. As a result, the average orange outputs were 39520 and $39270 \mathrm{ha}^{-1}$, respectively, in the analyzed enterprises. The total energy consumed during orange production was 51950.23 and $61723.95 \mathrm{MJ} \mathrm{ha}^{-1}$, respectively, and the energy equivalents of the outputs were 98848 and $94248 \mathrm{MJ} \mathrm{ha}^{-1}$ in the enterprises that applied and did not apply good agricultural practices (Table 2).

The findings indicated that in orange production, the share of energy consumed consists of $39.25 \%$ and $42.38 \%$ nitrogen, $11.11 \%$ and $8.99 \%$ diesel fuel, $8.16 \%$ and $9.49 \%$ phosphate and $9.29 \%$ phosphorus, $8.11 \%$ and $6.61 \%$ machinery, $6.62 \%$ and $5.74 \%$ electricity in enterprises that applied and did not apply good agricultural practices, respectively.

The result also showed that proportions of the other energy-consuming inputs for orange production in the enterprises that applied and did not apply good agricultural practices were $3.93 \%$ and $6.47 \%$ potassium, $4.89 \%$ and $4.25 \%$ irrigation water, $6.05 \%$ and $5.32 \%$ herbicides, $5.03 \%$ and $4.72 \%$ fungicides, $2.03 \%$ and $1.84 \%$ insecticides, $2.64 \%$ and $2.23 \%$ labor, $1.85 \%$, and $1.65 \%$ farmyard manure, $0.34 \%$, and $0.30 \%$ sulfate, respectively.

The most energy-consuming inputs in orange production were fertilizers. After fertilizers and pesticides, diesel, machinery, irrigation water, and electricity were the most energy-consuming inputs. The lowest energy-consuming inputs were determined as labor and farmyard manure. Ozkan et al. (2004) determined that the energy input of chemical fertilizer $(49.68 \%)$, primarily nitrogen, had the highest percentage of overall energy inputs in citrus (orange, tangerine, and lemon) production followed by diesel $(30.79 \%)$. In the study carried out by Namdari et al. (2011), diesel was the highest energy input, followed by fertilizers and water for irrigation. Loghmanpour et al. (2013b) stated that fertilizers used the most energy and were the most crucial energy inputs required in citrus-producing fields, followed by pesticides. Mohammadshirazi et al. (2015) determined that chemical fertilizers utilized the most energy (26.9\%), followed by chemicals (26.1\%).

Table 3 shows the quantities of the inputs required in tangerine production, their energy equivalences, the quantity of tangerine production, and the energy equivalent of the output. According to the results illustrated in Table $3,347.50$ and $360.50 \mathrm{~kg}$ nitrogen, 395 and $463.50 \mathrm{~kg}$ phosphorus, 343.00 and $327.50 \mathrm{~kg}$ potassium, 144 and $144 \mathrm{~kg}$ sulfate, 3200 and $3000 \mathrm{~kg}$ of farmyard manure, 102.50 and $95.00 \mathrm{I}$ diesel fuel, 4360 and $4580 \mathrm{~m}^{3}$ irrigation water, 9.30 and $11.20 \mathrm{~kg}$ insecticides, 12.80 and $12.20 \mathrm{~kg}$ fungicides, 13.50 and $13.00 \mathrm{~kg}$ herbicides, 726.80 and $689.00 \mathrm{~h}$ labor, 65.00 and $60.50 \mathrm{~h}$ machinery, 1085 and $1180 \mathrm{kWh}$ electrical energy per hectare was used for the tangerine production that applied and did not apply good agricultural practices, respectively. As a result, tangerine outputs were 39270 and $36350 \mathrm{ha}^{-1}$ on average, respectively. The total energy used during tangerine productions was 53862.19 and $58938.65 \mathrm{MJ} \mathrm{ha}^{-1}$, and the energy equivalents of the outputs were 94248 and $87240 \mathrm{MJ} \mathrm{ha}^{-1}$, respectively, in the enterprises that applied and did not apply good agricultural practices.

Table 3. Quantities of inputs and outputs and total energy equivalents of tangerine production.

\begin{tabular}{|c|c|c|c|c|c|c|}
\hline \multirow[b]{2}{*}{ Inputs } & \multicolumn{3}{|c|}{ GAP tangerine } & \multicolumn{3}{|c|}{ Tangerine } \\
\hline & $\begin{array}{l}\text { Quantity per } \\
\text { unit area } \\
\text { (ha) }\end{array}$ & $\begin{array}{l}\text { Energy } \\
\text { equivalent } \\
\text { (MJ) }\end{array}$ & $\begin{array}{c}\% \text { of total } \\
\text { energy } \\
\text { input }\end{array}$ & $\begin{array}{l}\text { Quantity per } \\
\text { unit area (ha) }\end{array}$ & $\begin{array}{c}\text { Energy } \\
\text { equivalent } \\
(\mathrm{MJ})\end{array}$ & $\begin{array}{c}\% \text { of total } \\
\text { energy } \\
\text { input }\end{array}$ \\
\hline Labor (h) & 726.80 & 1424.53 & 2.64 & 689.00 & 1350.44 & 2.29 \\
\hline Machinery (h) & 65.00 & 4212.00 & 7.82 & 60.50 & 3920.40 & 6.65 \\
\hline Diesel (I) & 102.50 & 5771.78 & 10.72 & 95.00 & 5349.45 & 9.08 \\
\hline $\begin{array}{l}\text { Farmyard manure }(\mathrm{kg}) \\
\text { Fertilizers }(\mathrm{kg})\end{array}$ & 3200.00 & 960.00 & 1.78 & 3000.00 & 900.00 & 1.53 \\
\hline Nitrogen & 347.50 & 21058.50 & 39.10 & 360.50 & 23843.47 & 40.45 \\
\hline Phosphorus & 395.00 & 4404.25 & 8.18 & 463.50 & 5765.94 & 9.78 \\
\hline Potassium & 343.00 & 2298.10 & 4.27 & 327.50 & 3651.63 & 6.20 \\
\hline Sulfate & 144.00 & 161.28 & 0.30 & 144.00 & 161.28 & 0.27 \\
\hline Pesticides (kg) & & & & & & \\
\hline Insecticides & 9.30 & 941.16 & 1.75 & 11.20 & 1133.44 & 1.92 \\
\hline Fungicides & 12.80 & 2764.80 & 5.13 & 12.20 & 2635.20 & 4.47 \\
\hline Herbicides & 13.50 & 3213.00 & 5.97 & 13.00 & 3094.00 & 5.25 \\
\hline Electricity (kWh) & 1085.00 & 3906.00 & 7.25 & 1180.00 & 4248.00 & 7.21 \\
\hline Irrigation water $\left(\mathrm{m}^{3}\right)$ & 4360.00 & 2746.80 & 5.10 & 4580.00 & 2885.40 & 4.90 \\
\hline Total & & 53862.19 & 100.00 & & 58938.65 & 100.00 \\
\hline Output (Yield) & 39270.00 & 94248.00 & & 36350.00 & 87240.00 & \\
\hline
\end{tabular}


According to the results, the proportions of energy consumption in tangerine production consisted of $39.10 \%$ and $40.45 \%$ nitrogen, 10.72 and $9.08 \%$ diesel fuel, $8.18 \%$ and $9.78 \%$ of phosphorus, $7.82 \%$ and $6.65 \%$ of machinery, $7.25 \%$ and $7.21 \%$ of electricity in the enterprises that applied and did not apply good agricultural practices respectively. Besides, the other energyconsuming inputs for tangerine production was $4.27 \%$ and $6.20 \%$ potassium, $5.10 \%$ and $4.90 \%$ irrigation water, $5.97 \%$ and $5.25 \%$ herbicides, $5.13 \%$ and $4.47 \%$ fungicides, $1.75 \%$ and $1.92 \%$ insecticides, $2.64 \%$ and $2.29 \%$ labor, $1.78 \%$ and $1.53 \%$ farmyard manure, $0.30 \%$ and $0.27 \%$ sulfate, respectively.

In enterprises that applied good agricultural practices, total fertilizers consumed the most energy, followed by pesticides, diesel fuel, machinery, electricity, irrigation water, labor, and farmyard manure. Fertilizers consumed the most energy, followed by pesticides, fuel, electricity, machinery, labor, and farmyard manure in the other group. Namdari et al. (2011) determined that the highest energy-consuming inputs were diesel fuel, chemical fertilizer, and water for irrigation with 24 , 23 , and $23 \%$ shares, respectively, in tangerine production. Mohammadshirazi et al. (2012) determined that fertilizers had the highest energy consumption in tangerine production. In the studies carried out by Karabat and Aydın (2018) and Yılmaz and Aydın (2020), fertilizers, pesticides, and diesel were determined to be the first three highest energy-consuming inputs in the enterprises. Bilgili (2021) determined that fertilizers were the highest energy-consuming inputs in tangerine production.

Table 4 shows the inputs required in lemon production (physical quantity per hectare), yield per hectare (output), and energy equivalents. The results showed that about 728.50 and $734.60 \mathrm{~h}$ labor, 59.50 and $61.50 \mathrm{~h}$ machinery, 88.00 and
$95.50 \mathrm{I}$ diesel, 3000 and $3500 \mathrm{~kg}$ farmyard manure, 374.00 and $433.50 \mathrm{~kg}$ nitrogen, 456.00 and $516.50 \mathrm{~kg}$ phosphorus, 320 and $396 \mathrm{~kg}$ potassium, 168 and $180 \mathrm{~kg}$ sulfate, 9.50 and $11.20 \mathrm{~kg}$ insecticides, 13.60 and $16.50 \mathrm{~kg}$ fungicides, 11.80 and $13.80 \mathrm{~kg}$ herbicides, 1150 and $1235 \mathrm{kWh}$ electricity and 4050 and $4360 \mathrm{~m}^{3}$ irrigation water were used per hectare for lemon production that applied and did not apply good agricultural practices. The total energy used in the enterprises were calculated as 54618.60 and $66741.21 \mathrm{MJ}$ ha${ }^{1}$, most of which was related to fertilizers $(55.08 \%$ and $59.51 \%)$, followed by pesticides $(12.28 \%$ and $11.96 \%)$, diesel $(9.07 \%$ and $8.06 \%)$, electricity (7.58\% and 6.66\%), machinery $(7.06 \%$ and $5.97 \%)$, irrigation water $(4.67 \%$ and $4.12 \%)$, labor $(2.61 \%$ and $2.16 \%)$ and farmyard manure $(1.65 \%$ and $1.57 \%$ ) in the enterprises that applied and did not apply good agricultural practices, respectively. Lemon yields were determined to be 37690 and $37290 \mathrm{~kg} \mathrm{ha}^{-1}$ on average. As a result, 90456 and $89496 \mathrm{MJ} \mathrm{ha}^{-1}$ were calculated as total energy output per hectare, respectively.

Bilgili (2012) reported that fertilizers were the highest energy inputs in lemon production, followed by fuel, pesticides, irrigation water, labor, and machinery. In contrast, the study by (Yilmaz and Aydın, 2020) found that fertilizers, chemicals, and diesel fuel were the most energy-consuming inputs in lemon production, respectively.

Table 5 shows the energy parameters in citrus production. The energy use efficiency (energy ratio) values were 1.83 and 1.53 in orange production, 1.75 and 1.48 in tangerine production, 1.66 and 1.34 in lemon production in the enterprises that applied and did not apply good agricultural practices, respectively. This revealed that energy usage in citrus production was efficient regardless of product type. In other words, energy production was more remarkable than energy utilization.

Table 4. Quantities of inputs and outputs and total energy equivalents of lemon production.

\begin{tabular}{|c|c|c|c|c|c|c|}
\hline \multirow[b]{2}{*}{ Inputs } & \multicolumn{3}{|c|}{ GAP lemon } & \multicolumn{3}{|c|}{ Lemon } \\
\hline & $\begin{array}{l}\text { Quantity per } \\
\text { unit area } \\
\text { (ha) }\end{array}$ & $\begin{array}{c}\text { Energy } \\
\text { equivalent } \\
(\mathrm{MJ})\end{array}$ & $\begin{array}{c}\% \text { of total } \\
\text { energy } \\
\text { input }\end{array}$ & $\begin{array}{l}\text { Quantity per } \\
\text { unit area (ha) }\end{array}$ & $\begin{array}{c}\text { Energy } \\
\text { equivalent } \\
(\mathrm{MJ})\end{array}$ & $\begin{array}{c}\% \text { of total } \\
\text { energy } \\
\text { input }\end{array}$ \\
\hline Labor (h) & 728.50 & 1427.86 & 2.61 & 734.60 & 1439.82 & 2.16 \\
\hline Machinery (h) & 59.50 & 3855.60 & 7.06 & 61.50 & 3985.20 & 5.97 \\
\hline Diesel (I) & 88.00 & 4955.28 & 9.07 & 95.50 & 5377.61 & 8.06 \\
\hline $\begin{array}{l}\text { Farmyard manure }(\mathrm{kg}) \\
\text { Fertilizers }(\mathrm{kg})\end{array}$ & 3000.00 & 900.00 & 1.65 & 3500.00 & 1050.00 & 1.57 \\
\hline Nitrogen & 374.00 & 22664.40 & 41.50 & 433.50 & 28671.69 & 42.96 \\
\hline Phosphorus & 456.00 & 5084.40 & 9.31 & 516.50 & 6425.26 & 9.63 \\
\hline Potassium & 320.00 & 2144.00 & 3.93 & 396.00 & 4415.40 & 6.62 \\
\hline Sulfate & 168.00 & 188.16 & 0.34 & 180.00 & 201.60 & 0.30 \\
\hline Pesticides (kg) & & & & & & \\
\hline Insecticides & 9.50 & 961.40 & 1.76 & 11.20 & 1133.44 & 1.70 \\
\hline Fungicides & 13.60 & 2937.60 & 5.38 & 16.50 & 3564.00 & 5.34 \\
\hline Herbicides & 11.80 & 2808.40 & 5.14 & 13.80 & 3284.40 & 4.92 \\
\hline Electricity (kWh) & 1150.00 & 4140.00 & 7.58 & 1235.00 & 4446.00 & 6.66 \\
\hline Irrigation water $\left(\mathrm{m}^{3}\right)$ & 4050.00 & 2551.50 & 4.67 & 4360.00 & 2746.80 & 4.12 \\
\hline Total & & 54618.60 & 100.00 & & 66741.21 & 100.00 \\
\hline Output (Yield) & 37690.00 & 90456.00 & & 37290.00 & 89496.00 & \\
\hline
\end{tabular}


Table 5. Energy parameters in orange, tangerine, and lemon production.

\begin{tabular}{lrrrrrr}
\hline Calculations & GAP orange & \multicolumn{1}{c}{ Orange } & GAP tangerine & Tangerine & GAP lemon & Lemon \\
\hline Total energy input $\left(\mathrm{MJ} \mathrm{ha}^{-1}\right)$ & 51950.23 & 61723.95 & 53862.19 & 58938.65 & 54618.60 & 66741.21 \\
Total energy output $\left(\mathrm{MJ} \mathrm{ha}^{-1}\right)$ & 94848.00 & 94248.00 & 94248.00 & 87240.00 & 90456.00 & 89496.00 \\
Energy use efficiency & 1.83 & 1.53 & 1.75 & 1.48 & 1.66 & 1.34 \\
Energy productivity $\left(\mathrm{kg} \mathrm{MJ}^{-1}\right)$ & 0.76 & 0.64 & 0.73 & 0.62 & 0.69 & 0.56 \\
Specific energy $\left(\mathrm{MJ} \mathrm{kg}^{-1}\right)$ & 1.31 & 1.57 & 1.37 & 1.62 & 1.45 & 1.79 \\
Net energy (MJ ha-1) & 42897.77 & 32524.05 & 40385.81 & 28301.36 & 35837.40 & 22754.79 \\
\hline
\end{tabular}

Nonetheless, the energy usage efficiency in citrus production was better when good agricultural practices were applied.

Previous researches on citrus production revealed energy usage efficiency values of 1.25 , 1.17 , and 1.06 in orange, tangerine, and lemon, respectively (Ozkan et al., 2004), 1.25 and 1.17 in orange and tangerine (Namdari et al., 2011), 0.87 in tangerine (Mohammadshirazi et al., 2012), 1.716 in all citrus (Loghmanpour et al., 2013b), 1.02 in lemon (Bilgili, 2012), 0.67 in orange (Mohammadshirazi et al., 2015), 2.24 and 2.04 in tangerine (Karabat and Aydın, 2018), 2.03 and 1.88 in tangerine, 1.82 and 1.58 in lemon (Yılmaz and Aydın, 2020), and 1.56 in tangerine production (Bilgili, 2021).

Energy consumption efficiencies in orange, tangerine, and lemon production were found to be higher than one. This was similar to earlier citrus production research findings, such as Ozkan et al. (2004), Namdari et al. (2011), Loghmanpour et al. (2013b), Bilgili (2012), Karabat and Aydn (2018), Yılmaz and Aydn (2020), Bilgili (2012) and Bilgili (2021). Furthermore, the energy usage efficiency of citrus production applied good agricultural practices was more remarkable in this study than citrus production did not apply good agricultural practices. The findings are similar to the studies conducted by Karabat and Aydın (2018) and Yılmaz and Aydın (2020).

Energy productivity is the term used to estimate the product yield per unit of energy consumption. Average energy productivity values were 0.76 and $0.64 \mathrm{~kg} \mathrm{MJ}^{-1}$ in GAP orange and orange production, 0.73 and $0.62 \mathrm{~kg} \mathrm{MJ}^{-1}$ in GAP tangerine and tangerine production, 0.69 and $0.56 \mathrm{~kg} \mathrm{MJ}^{-1}$ in GAP lemon and lemon production, respectively. This means that, for example, in orange production that applied good agricultural practices, $0.76 \mathrm{~kg}$ output was obtained for every $1 \mathrm{MJ}$ of energy consumed. When the production types were compared, it was discovered that citrus orchards that applied good agricultural practices could generate greater output than citrus orchards that did not apply good agricultural practices.

Specific energy was calculated as 1.31 and $1.57 \mathrm{MJ} \mathrm{kg}^{-1}$ in orange production, 1.37 and $1.62 \mathrm{MJ} \mathrm{kg}^{-1}$ in tangerine production, and 1.45 and $1.79 \mathrm{MJ} \mathrm{kg}^{-1}$ in lemon production, respectively in enterprises that applied and did not apply good agricultural practices. This means that, for example, in orange production, applied good agricultural practices. For producing one kg of orange, 1.31 MJ of energy was consumed. When the two production types were compared, enterprises that applied good agricultural practices used less energy to produce one kilogram of the product than those that did not apply good agricultural practices.

Net energy values for orange production were 42897.77 and 32524.05 $\mathrm{MJ} \mathrm{ha}^{-1}$, tangerine production was 40385.81 and $28301.36 \mathrm{MJ} \mathrm{ha}^{-1}$, and lemon production was 35837.40 22754.79 $\mathrm{MJ} \mathrm{ha}^{-1}$ in enterprises that applied good agricultural practices. According to calculations of energy use efficiency, citrus production was more profitable for companies that applied good agricultural practices.

Table 6 shows the distribution of input energy in citrus production by direct, indirect, renewable, and non-renewable energy sources. The majority of the energy input came from non-renewable and indirect sources. As shown in the table, the total energy input in orange production can be classified as direct $(25.26 \%$ and $21.21 \%)$, indirect $(74.74 \%$ and $78.79 \%)$, renewable $(9.38 \%$ and $8.13 \%)$, and nonrenewable $(90.62 \%$ and $91.87 \%)$ applied and did not apply good agricultural practices.

On average, the proportions of direct and indirect energy in enterprises in tangerine production that applied good agricultural practices was $25.71 \%$ and $74.29 \%$, while direct and indirect energy was $23.47 \%$ and $76.53 \%$ in tangerine production did not apply good agricultural practices. Also, renewable and non-renewable energy contributed to $9.53 \%$ and $90.47 \%$ of the total energy input in GAP tangerine production, whereas renewable and non-renewable energy contributed $8.71 \%$ and $91.29 \%$ tangerine production did not apply good agricultural practices.

Table 6 also demonstrated that the proportions of direct energy is lower (23.94\% and $20.99 \%)$ than indirect energy $(76.06 \%$ and $79.01 \%)$ of lemon producers who apply and do not apply good agricultural practices. Also, non-renewable and renewable energies contributed to $91.07 \%$ and $8.93 \%$ of the total energy input in GAP lemon production and $92.15 \%$ and $7.85 \%$ in lemon production.

Ozkan et al. (2004), Namdari et al. (2011), Bilgili (2012), Mohammadshirazi et al. (2012), Loghmanpour et al. (2013b), Mohammadshirazi et al. (2015), Karabat and Aydın (2018), Yılmaz and Aydın (2020) and Bilgili (2021) determined that the ratio of non-renewable energy was more significant than the ratio of renewable energy in citrus production.

The high non-renewable energy ratio in overall energy inputs has a detrimental impact on agricultural productivity and the environment. 
Table 6. Energy input forms of orange, tangerine, and lemon production.

\begin{tabular}{|c|c|c|c|c|c|c|}
\hline Energy form & GAP orange & Orange & GAP tangerine & Tangerine & GAP lemon & Lemon \\
\hline $\begin{array}{l}\text { Direct } \\
\text { energy a }\end{array}$ & $\begin{array}{l}13123.43 \\
(25.26 \%)\end{array}$ & $\begin{array}{l}13090.24 \\
(21.21 \%)\end{array}$ & $\begin{array}{l}13849.10 \\
(25.71 \%)\end{array}$ & $\begin{array}{l}13833.29 \\
(23.47 \%)\end{array}$ & $\begin{array}{l}13074.64 \\
(23.94 \%)\end{array}$ & $\begin{array}{l}14010.22 \\
(20.99 \%)\end{array}$ \\
\hline $\begin{array}{l}\text { Indirect } \\
\text { energy }{ }^{b}\end{array}$ & $\begin{array}{l}38826.80 \\
(74.74 \%)\end{array}$ & $\begin{array}{l}48633.71 \\
(78.79 \%)\end{array}$ & $\begin{array}{l}40013.09 \\
(74.29 \%)\end{array}$ & $\begin{array}{l}45105.36 \\
(76.53 \%)\end{array}$ & $\begin{array}{l}41543.96 \\
(76.06 \%)\end{array}$ & $\begin{array}{l}52730.99 \\
(79.01 \%)\end{array}$ \\
\hline $\begin{array}{l}\text { Renewable } \\
\text { energy }^{c}\end{array}$ & $\begin{array}{l}4873.66 \\
(9.38 \%) \\
\end{array}$ & $\begin{array}{l}5017.70 \\
(8.13 \%) \\
\end{array}$ & $\begin{array}{l}5131.33 \\
(9.53 \%) \\
\end{array}$ & $\begin{array}{l}5135.84 \\
(8.71 \%) \\
\end{array}$ & $\begin{array}{l}4879.36 \\
(8.93 \%) \\
\end{array}$ & $\begin{array}{l}5236.62 \\
(7.85 \%) \\
\end{array}$ \\
\hline $\begin{array}{l}\text { Non-renewable } \\
\text { energy d }\end{array}$ & $\begin{array}{l}47076.58 \\
(90.62 \%) \\
\end{array}$ & $\begin{array}{l}56706.25 \\
(91.87 \%) \\
\end{array}$ & $\begin{array}{l}48730.87 \\
(90.47 \%) \\
\end{array}$ & $\begin{array}{l}53802.81 \\
(91.29 \%) \\
\end{array}$ & $\begin{array}{l}49739.24 \\
(91.07 \%) \\
\end{array}$ & $\begin{array}{l}61504.60 \\
(92.15 \%) \\
\end{array}$ \\
\hline $\begin{array}{l}\text { Total energy } \\
\text { input }\end{array}$ & $\begin{array}{r}51950.23 \\
(100.00) \\
\end{array}$ & $\begin{array}{r}61723.95 \\
(100.00 \%) \\
\end{array}$ & $\begin{array}{r}53862.19 \\
(100.00 \%) \\
\end{array}$ & $\begin{array}{r}58938.65 \\
(100.00 \%) \\
\end{array}$ & $\begin{array}{r}54618.60 \\
(100.00 \%) \\
\end{array}$ & $\begin{array}{r}66741.21 \\
(100.00 \%) \\
\end{array}$ \\
\hline
\end{tabular}

a Includes labor, diesel, electricity, and irrigation water.

b Includes fertilizers, chemicals, farmyard manure, and machinery.

c Includes labor, farmyard manure, and irrigation water.

d Includes diesel, chemicals, fertilizers, machinery, and electricity.

However, the non-renewable energy ratio in the enterprises that applied good agricultural practices was lower than the enterprises in the other group. This result was similar to the studies carried out by Karabat and Aydın (2018) in tangerine production and Yılmaz and Aydın (2020) in citrus production.

\section{Conclusion}

Efficient and productive use of the energy sources is significant for all the countries in terms of economic development besides the supply of essential requirements. Evaluated in terms of agricultural production, citrus compose approximately $4 \%$ of the total fruit production areas in Turkey. For this reason, energy use is very important in terms of citrus products.

According to the results, the energy use efficiency in citrus production was higher in the enterprises that applied good agricultural practices in Mersin province. This result can be stated as the production inputs were used more controlled in the enterprises applied good agricultural practices. Therefore, it is suggested that especially the producers who did not apply good agricultural practices should be trained in input usage.

Renewable energy inputs were mainly diesel and electricity, whereas fertilizers and pesticides dominated nonrenewable inputs. This situation demonstrates that citrus production was significantly dependent on nonrenewable energy input. Inputs remained low with fertilizers, chemicals, diesel fuel, electricity, irrigation water, machinery, labor, and farmyard manure. The use of appropriate fertilizers and pesticides may lower the indirect energy requirements for pest control and manure.

According to the findings, the existing energy consumption pattern in the orchards is dependent on non-renewable energy. In other words, the proportion of renewable energy used in the orchards surveyed was low. Therefore, reducing the total non-renewable energy ratio, especially fertilizer use, would positively affect the sustainability of citrus production and positive environmental effects.
Considering the results of this study, it was determined that the generalization of good agricultural practices was essential. As a result, the subsidy levels offered to producers who apply good agricultural practices should be increased, and purchase guarantees for products produced using good agricultural practices should be offered. Furthermore, producer training in this area should be kept up to date. Regulation changes can be done for continuous producer training and incorporating the agricultural agents into the training. The producers' demands and suggestions should be evaluated as essential technical applications and should be within the regulations and directions of good agricultural practices.

\section{References}

Akcaoz, H. (2011). Analysis of energy use for banana production: a case study from Turkey. African Journal of Agricultural Research, 6:5618-5624.

Akcaoz, H., Ozcatalbas, O., \& Kizilay, H. (2009). Analysis of energy use for pomegranate production in Turkey. Journal of Food Agriculture and Environment, 7:475480.

Akdemir, S., Akcaoz, H., \& Kizilay, H. (2012). An analysis of energy use and input costs for apple production in Turkey. Journal of Food Agriculture and Environment, 10:473-479.

Anonymous (2020). Narenciye (Turunçgiller) Sektör Raporu. Nazilli Ticaret Odası Yayınları (in Turkish).

Anonymous (2021a). İstatistik göstergeler. Available at http://www.tuik.gov.tr. Date accessed May 25, 2021.

Anonymous (2021b). https://www.tarimorman.gov.tr /Konular/Bitkisel-Uretim/lyi-Tarim-Uygulamalari. Date accessed May 25, 2021.

Aydın, B., \& Aktürk, D. (2018). Energy use efficiency and economic analysis of peach and cherry production regarding good agricultural practices in Turkey: $A$ case study in Çanakkale Province. Energy, 158:967974.

Aydın, B., Aktürk, D., Özkan, E., Hurma, H., \& Kiracı, M.A. (2019). Comparative energy use efficiency and economic analysis of apple production in Turkey: Case of Thrace Region. Springer, Erwerbs-Obstbau, 6:39-45.

Banaeian, N., Omid, M., \& Ahmadi, H. (2011). Energy and economic analysis of greenhouse strawberry production in Tehran province of Iran. Energy Conversion and Management, 52:1020-1025. 
Baran, M.F., Lule, F., \& Gokdogan, O. (2017a). Energy input-output analysis of organic grape production: a case study from Adıyaman province. ErwerbsObstbau, 59:275-279.

Baran, M.F., Oguz, H.I., \& Gokdogan, O. (2017b). Determination of energy input-output analysis in organic strawberry production. Fresenius Environmental Bulletin, 26:2076-2081.

Baran, M.F., Oguz, H.I., \& Gokdogan, O. (2017c). Determining the energy usage efficiency of walnut (Juglans Regia L.) cultivation in Turkey. ErwerbsObstbau, 59:77-82.

Baran. M.F, Gökdoğan. O, \& Oğuz, H.I. (2017d). Determining of energy input-output analysis in plum (Prunus domestica L.) production. ErwerbsObstbau, 59:331-335.

Baran, M.F., Eren, O., Gokdoğan, O., \& Oğuz, H.I. (2020). Determination of energy efficiency and greenhouse gas (GHG) emissions in organic almond production in Turkey. Erwerbs-Obstbau, 62:341-346.

Beigi, M., Torki-Harchegani, M., \& Ghanbarian, D. (2016). Energy use efficiency and economical analysis of almond production: A case study in Chaharmahal-VaBakhtiari province, Iran. Energy Efficiency, 9:745-754.

Bilgili, M.E. (2012). Limon üretiminde enerji kullanım etkinliğinin belirlenmesi: Adana ili örneği. Tarım Makinaları Bilimi Dergisi, 8: 99-203 (in Turkish).

Bilgili, M.E. (2021). Energy use efficiency of mandarin production: A case study from Adana province. Erwerbs-Obstbau, 63:61-64.

Celen, İ.H., Baran, M.F., Onler, E., \& Bayhan, Y. (2017). Determination of energy balance of apple (Malus domestica) production in Turkey: A case study for Tekirdağ province. Anadolu Journal of Agricultural Sciences, 32:40-45.

Demircan, V., Ekinci, K., Keener, H.M., Akbolat, D., \& Ekinci, C. (2006). Energy and economic analysis of sweet cherry production in Turkey: A case study from Isparta province. Energy Conversion and Management, 47:1761-1769.

Dilay, Y., Özkan, A., \& Aydın C. (2010). Karaman ili elma üretiminde enerji bilançosu ve enerji kullanım etkinliğinin belirlenmesi. 26. Tarımsal Mekanizasyon Ulusal Kongresi, 22-23 Eylül 2010, Hatay, Bildiriler Kitabı s: 400:405 (in Turkish).

Ekinci, K., Akbolat, D., Demircan, V., \& Ekinci, C. (2005). Isparta ili elma üretiminde enerji kullanım etkinliğinin belirlenmesi. 3. Yenilenebilir Enerii Kaynakları Sempozyumu, 19-21 Ekim 2005, Mersin (in Turkish).

Esengun, K., Gunduz, O., \& Erdal, G. (2007). An inputoutput energy analysis in dry apricot production of Turkey. Energy Conversion and Management, 48:592-598.

Fadavi, R., Keyhani, A., \& Mohtasebi, S.S. (2011). An analysis of energy use, input costs and relation between energy inputs and yield of apple orchard. Research in Agricultural Engineering, 57:88-96.

Gezer, I., Acaroglu, M., \& Haciseferogullari, H. (2003). Use of energy and labor in apricot agriculture in Turkey. Biomass Bioenergy, 24:215-219.

Gokdogan, O., Baran, \& M.F. (2017a). Determination of energy use efficiency of some apple (Malus $x$ domestica) production in Turkey: a case study of Egirdir region. Erwerbs-Obstbau, 59:13-18.

Gokdogan, O., Oğuz, H.İ, \& Baran, M.F. (2017b). Energy input-output analysis in organic mulberry (Morus spp.) production in Turkey: A case study Adiyaman-Tut Region. Erwerbs-Obstbau, 59:325-330.

Göktolga, Z.G., Gözener, B., \& Karkacier, O. (2006). Şeftali üretiminde enerji kullanımı: Tokat ili örneği,
Gaziosmanpaşa Üniversitesi Ziraat Fakültesi Dergisi, 23:39-44 (in Turkish).

Gundogmus, E. (2006). Energy use on organic farming: A comparative analysis on organic versus conventional apricot production on small holdings in Turkey. Energy Conversion and Management, 47:3351-3359.

Gundogmus, E. (2013). Modelling and sensitivity analysis of energy inputs for walnut production. Actual Problems of Economics, 2:188-197.

Hasdemir, M. (2011). Kiraz yetiştiriciliğinde iyi tarım uygulamalarının benimsenmesini etkileyen faktörlerin analizi. Doktora Tezi, Ankara Üniversitesi, Ankara (in Turkish).

Karabat, S., \& Aydın, B. (2018). İyi tarım uygulamalarının mandarin üretiminde enerji kullanım etkinliği ve ekonomik analiz üzerine etkisi: İzmir ili örneği. Toprak Su Dergisi, 7:1-10 (in Turkish).

Kizilaslan, H. (2009). Input-output energy analysis of cherries production in Tokat province of Turkey. Applied Energy, 86:1354-1358.

Liu, Y., Langer, V., Jensen, H.H., \& Egelyng, H. (2010). Energy use in organic, green and conventional pear producing systems-cases from China. Journal of Sustainable Agriculture, 34:630-646.

Loghmanpor, R., Tabatabaekoloor, R., \& Akram, A. (2013a). Input-output energy and economic analysis of strawberry production in Iran. American Journal of Engineering Research, 2:173-177.

Loghmanpor, R., Tabatabaekoloor, R., \& Akram, A. (2013b). Energy use in citrus production of Mazandaran province of Iran. African Crop Science Journal, 21:61-65.

Mandal, K.G., Saha, K.P., Ghosh, P., Hati, K.M., \& Bandyopadhyay, K.K. (2002). Bioenergy and economic analysis of soybean based crop production systems in central India. Biomass Bioenergy, 23:337345.

Mohammadi, A., Rafiee, S., Mohtasebi, S.S., \& Rafiee, H. (2010). Energy inputs-yield relationship and cost analysis of kiwifruit production in Iran. Renewable Energy, 35:1071-1075.

Mohammadshirazi, A., Akram, A., Rafiee, S., Avval, S.Y.M., \& Kalhor, E.B. (2012). An analysis of energy use and relation between energy inputs and yield in tangerine production. Renewable and Sustainable Energy Review, 16:4515-4521.

Mohammadshirazi, A., Akram, A., Rafiee, S., \& Kalhor, E.B. (2015). On the study of energy and cost analyses of orange production in Mazandaran province. Sustainable Energy Technologies and Assessments, 10:22-28.

Namdari, M., Kangarshahi, A.A., \& Amiri, N.A. (2011). Input-ouput energy analysis of citrus production in Mazandaran province of Iran. African Journal of Agricultural Research, 6:2558-2564.

Oğuz, H.İ, Gökdoğan, O., \& Baran, M.F. (2019a). Determination of energy balance in organic wolfberry (Lycium barbarum L.) production in Turkey. Erwerbs-Obstbau, 61:61-66.

Oğuz, H.İ., Erdoğan, O., \& Gökdoğan, O. (2019b). Energy use efficiency and economic analysis of nectarine (Prunus persica var. nucipersica) production: A case study from Niğde province. Erwerbs-Obstbau, 61:323329.

Ozkan, B., Akcaoz, H., \& Karadeniz, F. (2004). Energy requirement and economic analysis of citrus production in Turkey. Energy Conversion and Management, 45:1821-1830. 
Qasemi Kordkheili, P., \& Rahbar, A. (2015). Modeling and optimization of energy consumption for grapefruit production in Iran. CIGR Journal, 17:118-129.

Qasemi Kordkheili, P., Kazemi, N., Hemmati, A., \& Taki, M. (2013). Energy consumption, input-output relationship and economic analysis for nectarine production in Sari region, Iran. International Journal of Agriculture and Crop Sciences, 5:125-131.

Rafiee, S., Seyed, H., Mousavi, A., \& Ali, M. (2010). Modeling and sensivity analysis of energy inputs for apple production in Iran. Energy, 35:3301-3306.

Royan, M., Khojastehpour, M., Emadi, B., \& Mobtaker, H.G. (2012). Investigation of energy inputs for peach production using sensivity analysis in Iran. Energy Conversion and Management, 64:441-446.

Sami, M., Shiekhdavoodi, M.J., \& Asakereh, A. (2011). Energy use of apple production in the Esfahan province of Iran. African Crop Science Journal, 19:125-130.

Singh, H., Mishra, D., \& Nahar, N.M. (2002). Energy use pattern inproduction agriculture of a typical village in Arial Zone, India-Part I. Energy Conversion and Management, 43:275-286.

Strapatsa, A.V., Nanos, G.D., \& Tsatsarelis, C.A. (2006) Energy flow for integrated apple production in Greece.
Agricultural Ecosystem and Environment, 116:176180.

Tabatabaie, S.M.H., Rafiee, S., Keyhani, A., \& Heidari, M.D. (2013). Energy use pattern and sensitivity analysis of energy inputs and input costs for pear production in Iran. Renewable Energy, 51:7-12.

Uysal, O., \& Polatöz, S. (2017). Dünyada ve Türkiye'de turunçgil üretimi ve diş ticareti. Türkiye Tohumcular Birliği Dergisi, 6-11 (in Turkish).

USDA. (2020). www.usda.gov.tr. Date accessed May 25 2021.

Yaldız, O., Öztürk, H.H., Zeren, Y., \& Başçetinçelik, A. (1993). Energy Use in Field Crops of Turkey. 5. International Congress of Agricultural Machinery and Energy, Kuşadası, Turkey.

Yılmaz, I., Özalp, A., \& Aydoğmuş, F. (2010). Antalya ili bodur elma üretiminde enerji kullanım etkinliğinin belirlenmesi: Elmalı ilçesi örneği. Akdeniz Üniversitesi Ziraat Fakültesi Dergisi, 23:93-97 (in Turkish).

Yılmaz, H., \& Aydın, B. (2020). Comparative input-output energy analysis of citrus production in Turkey: Case of Adana province. Erwerbs-Obstbau, 62:29-36. 